\title{
Tennessee Williams' Ecological Awareness in His Plays Guo-Ping AN
}

\author{
Foreign Language Institute of North China Electric Power University, Baoding, Hebei, China
}

No. 213 mail-box of Foreign Language Institute of North China Electric Power University, 071003 anguoping1015@yeah.net

\section{Keywords: Tennessee Williams, ecological awareness, industrialization, plays}

\begin{abstract}
As an American dramatist, Tennessee Williams has been regarded as one of the greatest playwrights after Eugene O'Neill in the $20^{\text {th }}$ century. With the popularity of eco-criticism, his ecological awareness has aroused researchers' concern. This paper attempts to explore Williams' ecological awareness from four aspects: his description about nature, people's living surroundings, his portrayal of animal images and his concern about the characters' spiritual ecology. The paper also probes into the sources of Williams' ecological consciousness: his intimacy with nature and the influence of other ecological writers. This paper aims to provide a new perspective to study on Tennessee Williams' works.
\end{abstract}

\section{Introduction}

In recent years, the intensified conflicts between man and nature arouse eco-criticism. In The Song of the Earth, Jonathan Bate describes the ecological crisis in the world vividly. Bate thinks since the turn of $20^{\text {th }}$ century, nature has become endangered because of the ecological crisis, as a result, the benefits of human being have been greatly affected. (Bate, 2000) Since 1960's, with the growing number of crisis, the cross-subject research related with ecology has been established in almost every subject, such as eco-philosophy, eco-ethics, eco-sociology. Eco-criticism belongs to one of subjects. Until 1990s, eco-criticism has become predominant literary study. Just as a Chinese professor Zhang shengzhen once said: "The theory of eco-criticism does not absorb the concrete methodology and research results of natural science, but rather assimilate the basic ideology of the science of ecology: the views of wholeness, the connectedness of things and the harmony of viewing the universe. "(Zhang, 2009, 13)

In a word, eco-criticism provides a new perspective in drama field. Tennessee Williams has won two Pulitzer Prizes and four New York Drama Critics Circle Awards. Williams' achievement has aroused many critics' attention. They have analyzed Williams from five perspectives, such as gender, biology, culture, identity and psychoanalysis. Eco-criticism has covered literature fields, such as poetry, novel. But drama field has been neglected for a long time. Few researches have been done on Tennessee Williams' ecological awareness. This paper intends to explore this theme from four aspects: his description about nature, people's living surroundings, his portrayal of animal images and his concern about the characters' spiritual ecology.

\section{Williams' Ecological Awareness in His Plays}

\section{Williams' Description about Nature}

Though most of Williams' plays are set in industrial cities, natural description still occupies its place in Williams' plays, especially in his early works. Williams usually uses Southern plantation to represent the natural world. In The Glass of Menagerie, Amanda depicts the lovely scenery in May. "Afternoons, long and long rides! Picnics--lovely!--So lovely, that country in May!-all lacy with dogwood, literally flooded with jonquil!--that was the spring I gad craze with jonquils. Jonquils absolutely had an absolute obsession."(Williams, 1944) The beautiful scenery of Southern 
plantation attracted Amanda deeply. Through the description, Williams constructed a beautiful natural world about the South.

In Scene VII of The Glass of Menagerie, Williams depicts the beautiful scenery of the setting: "There is a steady murmur of rain, but it is slackening and stops soon after the scene begins; the air outside becomes pale and luminous as the moon breaks out." (Williams, 1944) With the natural scenery paved the way of dim surrounding, the new floor lamp with its shade of rose-colored silk gave a soft, becoming light to Amanda's face, bringing out the fragile, unearthly prettiness. The description of the moon appears several times in The Glass of Menagerie. The moon looked cold, but peaceful and beautiful. Tom's closing speech showed his feelings about the moon: "I didn't go to the moon...I traveled around a great deal. The cities swept about me like dead leaves, leaves that were brightly colored but torn away from the branches. " (Williams, 1944) Tennessee compared Tom to dead leaves because of his depression about the industrial world. His longing for the balance between human and nature was clearly shown.

In A Street Car Named Desire, there is a similar description about the natural scenery. "It is first dark of an evening early in May. The sky that shows around the dim white building is a peculiar tender blue, almost turquoise, which invests the scene with a kind of lyricism and gracefully attenuates the atmosphere of decay. You can almost feel the warm breath of the brown river beyond the river warehouses with their faint redolence of bananas and coffee."(Williams, 1947)The beautiful scenery was far from the city life in New Orleans. In Scene VIII,there is natural description of the sunset. "The view through the big windows is fading gradually into still-golden dusk. A torch of sunlight blazes on the side of a big water-tank or oil-drum across then empty lot towards the business district, which is now pierced by pin-points of lighted windows or windows reflecting the sunset." (Williams, 1947)The glorious scenery of sunset appeared out of the window, however, it would fade in a short time, symbolizing Blanche's becoming mentally ill.

All the descriptions of natural world imply the ecological awareness of Tennessee Williams, the dissatisfaction of industrialization and the desire of going back to natural world.

\section{Williams' Description about People's Living Surrounding}

Williams created ecological stage effect through scene-setting, which focuses on the surroundings. The natural environment has formed a sharp contrast with the reality. Compared with where Amanda lived, the reality is so harsh: "The Wingfield apartment is in the rear part of the building, one of those vast hive-like conglomerations of cellular living units that flower as warty growths in overcrowded urban centers of lower middle-class population and are symptomatic of the impulses of this largest and fundamentally enslaved section of American society to avoid fluidity and differentiation and to exist and function as one interfused mass of automatism."(Williams, 1944)

In A Street Car Named Desire, there is a similar description about the living condition. "The houses are mostly white frame, weathered grey, with rickety outside stairs and galleries and quaintly ornamented gables." (Williams, 1947)In fact, Williams described many Americans' limited living environment. The change is due to the industrialization. The fast development of industry does not bring happiness to people, on the contrary, it brings people more material and spiritual pain. Even, the name of the apartment "Wingfield" implies that people living here are longing for escaping from the terrible environment. Then, what is the ideal living place? Tennessee expressed his longing for going back to his memory's life. In scene V of The Glass of Menagerie, Amanda was often immersed into the old memory. She still hoped she could live on a Mississippi veranda, without any intension and panic. In A Street Car Named Desire, Blanche always mentioned Belle Reve. For her, Belle Reve carried all her beautiful memories.

Williams was not only proud of his southern origin but also revered elegant and dignified world that had already gone. The childhood that he spent in the southern area was so fantastic like a beautiful Garden of Eden. The old southern culture, picturesque rural scenery and mysterious natural people left a deep impression in Williams. However, after moving to the northern industrial city, his childhood became miserable. He often felt suffocated since he had lost freedom forever. 
"Williams, like his favorite poet Wordsworth and Blake, considered growth as a process of losing innocence and joy. These images were deeply branded in dramatist's memory." (Matthew, 2000:160) In William's eyes, the elegant idyllic world became the shelter for people to escape from the industrial world.

\section{William's Portrayal of the Animal Images}

Darwin's evolution theory advocates "survival of the fittest". Since ancient times, human being and other animals have struggled brutally in order to survive. In the $20^{\text {th }}$ century, with the rapid development of machinery industry and the more tense social competition, people show their indifference, the greed for material needs and the imprudence of sexual relationship. As a modern dramatist, Tennessee Williams discovered human's animal instinct. In his plays, there are many animal images, such as The Glass of Menagerie, Cat on a Hot Tin Roof, The Night of the Iguana, Not about Nightingales and Sweet Birds of Youth. Although there is no direct animal image in $A$ Street Car Named Desire, animal images do appear in the play, such as canary, ape and other images. In The Glass of Menagerie, Williams created some glass animals to convey his ideal world where people could live peacefully without any fights. A Street Car Named Desire and Cat on a Hot Tin Roof imply human's desire and greed. As Williams' later works, The Night of the Iguana reflects the recovery of humanity. The themes are nothing less than the ecological awareness of the dramatist.

\section{William's Concern about the Characters' Spiritual Ecology}

In the 1930s and 1940s, American society had undergone great changes. The industrialization and the Great Depression gave the southern society a heavy blow. Southerners suffered from experiencing poverty hardship and ragged living environment. Their life was filled with frustration, depression and loss. The criticism of industrial civilization and the recall of the Southern plantation era are the main manifestation of Williams' ecological awareness.

For example, in The Glass of Menagerie, Wingfield family lived a poor life since Amanda's husband abandoned the family. Amanda was reluctant to face the reality, so she was indulged in the memory of the past since the recall of glorious deeds gave her a sense of self-worth. As a mother, she failed to give her children enough encouragement and support. With the impact of capitalist values, Amanda regarded materialism and consumerism as her code of conduct. When dealing with the relationship with her children, Amanda regarded them as commodities or objects, which made her alien from the family. In the play, Amanda hoped her daughter Laura to marry someone who can help them out of financial trouble instead of someone who Laura really loved.

In Cat on a Hot Tin Roof, Margaret married to Brick in order to escape poverty, but found herself unfulfilled. The relationship between husband and wife was indifferent. Their marriage existed only in name. When Margaret knew Big Daddy was going to die, she lied to the dying man that she loved his son, and she even played a trick to grab more heritages by fake pregnancy. Big Mama acted as a shopaholic on her trip of Europe, which revealed her pursuing material life. Big Daddy occupied large quantity of treasure. However, when he was dying, he was not happy at all. The trust between people has been broken down. This is a result of money-worship brought by industrialization. Williams' care about people's spiritual world reflects his ecological awareness.

\section{Origin of Williams' Ecological Awareness}

\section{Tennessee Williams' Intimacy with Nature}

Tennessee Williams was born in Columbia, Mississippi. According to geography, Mississippi Delta was a vegetation lush land. People enjoyed the beauty of nature. The soil was fertile due to the deposits accumulated from Mississippi river basin, which was an ideal place for cotton cultivation. In his childhood, he lived with his mother and sister in Clarkdale, a picturesque small town of southern US. The Mississippi River and Sunflower River were crossing the town. The vast plains lay at the river bank. Huge cypress was bathing in the grave and solemn ceremony $\cdots$ The endless 
cotton fields were full of vigor. At the other side of the river, there were orderly avenues, business area, parks and houses. (Williams, 1975) when he was eight, he had to move to St. Louis because of his father. Though living in a fast-developed city, Williams could not integrate into the consumerism-oriented living atmosphere. Williams was filled with a sense of loss. In his eyes, St.Louis was "a city with fear" and "a city with pollution". In 1925, as a teenager, Williams published an ecological poem entitled "Demon Smoke" to show his protest against pollution during the industrialization. In later works, he still concerned about nature in an indirect way.

Tennessee Williams' ecological awareness originates from his own experience and his strong feelings of southern culture. Williams ever said the southern US was not only his hometown with wonderful childhood memories but also his spiritual home forever. His enthusiasm for traditional southern culture, especially the special feelings of Mississippi Delta and New Orleans, inspired him and provided him with writing materials.

\section{Influence of Other Ecological Writers}

Williams ever mentioned that he was inspired by Anton Chekhov, Hart Crane and D.H. Lawrence. Lawrence influenced Williams greatly. Lawrence loved nature so much that he always put himself into nature as if the civilized world did not exist. He felt disgusted about the industrial town. He thought the result of the industrialization was the destruction of human being. In order to conquer nature, human being invented many machines and the machines became human being's new "God". Lawrence once predicted the post-industrialized society with a lot of machines. In his works Twilight in Italy, Lawrence wrote the crisis of industrialization. What would the world look like? It seemed like the black color covered London and other industrial cities. Lawrence lamented mechanization and people's painful life, which expressed his ecological awareness.

As the inheritor, Tennessee Williams got the influence from Lawrence, just as he once put it in Memoirs: "it has often been said that Lawrence was my major literary influence. Well, Lawrence was indeed a highly simpatico figure in my up-bringing."(1975:41)

\section{Conclusion}

As one of the greatest dramatists in the $20^{\text {th }}$ century, Tennessee Williams has attracted lots of critics to conduct research on his plays. Tough he is a not an ecologist in a strict sense, we can find his ecological awareness through his plays. Tennessee Williams' aspiration towards nature and concern about ordinary people's pain makes him stand out the other dramatists, just as Leverich comments: Williams was concerned with "the depths and origin of human feelings and motivations, the difference being that he had gone into a deeper, more obscure realm, which, of course, put the poet in him to the fore, and not the playwright who would bring much concern for audience and critical reaction".

\section{Acknowledgement}

This research is financially supported by the Fundamental Research Funds for the Central Universities (Grant NO. 2017MS182).

\section{References}

[1] Bate, Jonathan. The Song of the Earth. Cambridge: Harvard University Press, 2000.

[2] Bloom, Harold, ed. Introduction to Tennessee Williams. New York: Chelsea House, 1987.

[3] Delvin, Albert J,ed. Conversations with Tennessee Williams. Jackson, Ms: UP of Mississippi, 1986.

[4] Falk, L. Signi. Tennessee Williams.Boston: Twayne Publishers, 1978. 
[5] Fedder, Norman J. The Influences of D.H. Lawrence on Tennessee Williams. The Hague: Mounton \& Co., Publishers, 1996.

[6] Mathew C., ed. The Cambridge Companion to Tennessee Williams. Shanghai: Shanghai Foreign Language Education Press, 2000.

[7] Williams, Tennessee. A Street Car Named Desire. New York: New Direction, 1947.

[8] Williams, Tennessee. Cat on a Hot Tin Roof. New York: Dramatists Play Service, 1995.

[9] Williams, Tennessee. Memoirs. Garden City: Doubleday, 1975.

[10]Williams, Tennessee. The Glass Menagerie. New York: Random House, 1944.

[11]Williams, Tennessee. The Night of the Iguana. New York: New Directions Publishing, 1961.

[12] Shengzhen Zhang, A Study of Eugene O'Neill's Ecological Awareness in His Plays[M], Doctor Thesis of Shandong University,2009.

[13]Bing Wang, A Study of Tennessee Williams'Ecological Awareness: With the Examples of Four New York Drama Critics' Circle Prize Plays [M], Master Thesis of Beijing Transportation University,2016. 